\title{
ЭФФЕКТИВНОСТЬ НОВЫХ ИНСЕКТИЦИДОВ И ИХ ВЛИЯНИЕ НА ОПЫЛИТЕЛЕЙ В ПОСЕВАХ РАПСА
}

\author{
Кулагин О.В., Кудашкин П.И., Иванова И.А. \\ Сибирский федеральный научный центр агробиотехнологий Российской академии наук; \\ Новосибирская область, p.n. Краснообск, Россия; olegwk61@ yandex.ru
}

\begin{abstract}
The data on the effectiveness of new preparations of JSC "Shchelkovo Agrokhim" in the fight against rape blossom beetle on rapeseed in the forest-steppe of Western Siberia were obtained. The preparations have shown high efficiency in the fight against the pest. An increase in the number of pollinators found in plots treated with insecticides
\end{abstract}

Keywords: rapeseed, rape blossom beetle, pollinators, insecticides, efficiency.

\section{Введение}

Рапс является важной масличной культурой. Его посевы в Новосибирской области в 2018-2019 гг. достигли 90-99 тыс. га [1]. Однако в Западной Сибири он сильно повреждается вредителями. В настоящее время наиболее надежным способом ограничения их вредоносности остается химический метод. Наряду с пиретроидными инсектицидами, которые испытывались в наших условиях [2], в последние годы на российском рынке появились неоникотиноидные препараты, в частности на основе имидаклоприда. Они также требуют испытаний в условиях лесостепи Западной Сибири в конкретных климатических и фитосанитарных условиях.

\section{Материалы и методы}

Ранее в Новосибирской области проводились опыты по испытанию новых инсектицидов АО «Щелково Агрохим» против вредителей на рапсе [3]. В 2020 г. были продолжены испытания, начатые в 2019 г. с расширенным списком препаратов. Посев рапса сорта СибНИИК 198 проводился 15 мая семенами, протравленными смесью препаратов Скарлет, МЭ (0,4 л/т)+Эмистим, Ж (1мл/т) + Харита, КС (5,8 л/т) + Биостим Старт (1 л/т). Применение данной смеси, как и в прошлом году, сдерживало численность земляных блошек на уровне 35-90 экз./ ${ }^{2}$. Площадь делянки составляла 27 м $^{2}$. Обработка инсектицидами (схема см. табл. 1) проводилась 26.06 ручным опрыскивателем с расходом рабочего раствора 200 л/га. Учет цветоеда осуществлялся путем отряхивания жуков с растения.

\section{Результаты и обсуждение}

В отличие от прошлого года, лет капустной моли и рапсового пилильщика был крайне слабым, в дальнейшем на растениях рапса отмечали лишь единичных личинок. Напротив, в связи с теплой и ранней весной, развитие популяции цветоеда было обильным. Выход жуков с мест зимовки отмечался в конце апреля. Отдельные жуки “проверяли” посев рапса с фазы 1-2 пары настоящих листьев. В фазе розетки цветоед обнаруживался на листьях и в пазухах черешков листьев рапса. При появлении первых бутонизирующих растений (22.06) цветоед концентрировался на них, численность достигала 50 шт./растение.

Инсектициды по-разному подавили численность цветоеда. Эсперо, Эсперо Евро, Беретта, Амплиго были наиболее эффективны - 100\% на 3-и сутки, 95-98\% на 5-е. Другие препараты (Кораген, Апекс, Локустин (как и в прошлом году) были хуже (табл. 1) 
Эффективное подавление цветоеда в фазе бутонизации в дальнейшем хорошо было видно в период цветения. На делянках, обработанных инсектицидами, оно началось немного раньше и было визуально более обильным.

Таблица 1.- Биологическая эффективность (\%) инсектицидов в борьбе с рапсовым цветоедом

\begin{tabular}{|l|l|l|l|l|}
\hline \multirow{2}{*}{$\begin{array}{l}\text { Вариант, норма расхода, } \\
\text { л/га }\end{array}$} & \multicolumn{4}{|l|}{ Сутки после обработи } \\
\cline { 2 - 5 } & 3 -е & $5-\mathrm{e}$ & 7 -е & 10 -е \\
\hline Контроль & 1,86 & 4,5 & 1,9 & 1,7 \\
\hline Эсперо, КС, 0,2 & 100 & 100 & 97,9 & 84,7 \\
\hline Эсперо Евро, МД, 0,4 & 100 & 94,7 & 91,6 & 80 \\
\hline Беретта, МД, 0,4 & 100 & 100 & 89,5 & 74,1 \\
\hline Кораген, КС, 0,2 & 90,3 & 58,7 & 17,9 & 69,4 \\
\hline Локустин, КС, 0,4 & 89,2 & 77,3 & 60 & 50,6 \\
\hline Апекс, МД, 0,5 & 81,7 & 64,4 & 49,5 & 67,1 \\
\hline Пирелли, КЭ, 1,0 & 96,8 & 87,5 & 61,0 & 57,6 \\
\hline Амплиго, МКС, 0,3 & 100 & 96,9 & 98,9 & 83,5 \\
\hline
\end{tabular}

*- в контроле приведена абсолютная численность, шт./раст.

В период массового цветения были проведены учеты крупных опылителей способом сплошного подсчета на делянке. Среди опылителей доминировали шмели рода Bombus, встречались Apis melifera, другие одиночные пчелы, осы, сирфиды. Первый учет показал, что в целом, на вариантах с более эффективными против цветоеда инсектицидами, опылителей было больше чем на контроле. В дальнейшем на всех инсектицидных делянках (кроме Амплиго) опылителей было больше чем на контроле (рис.1)

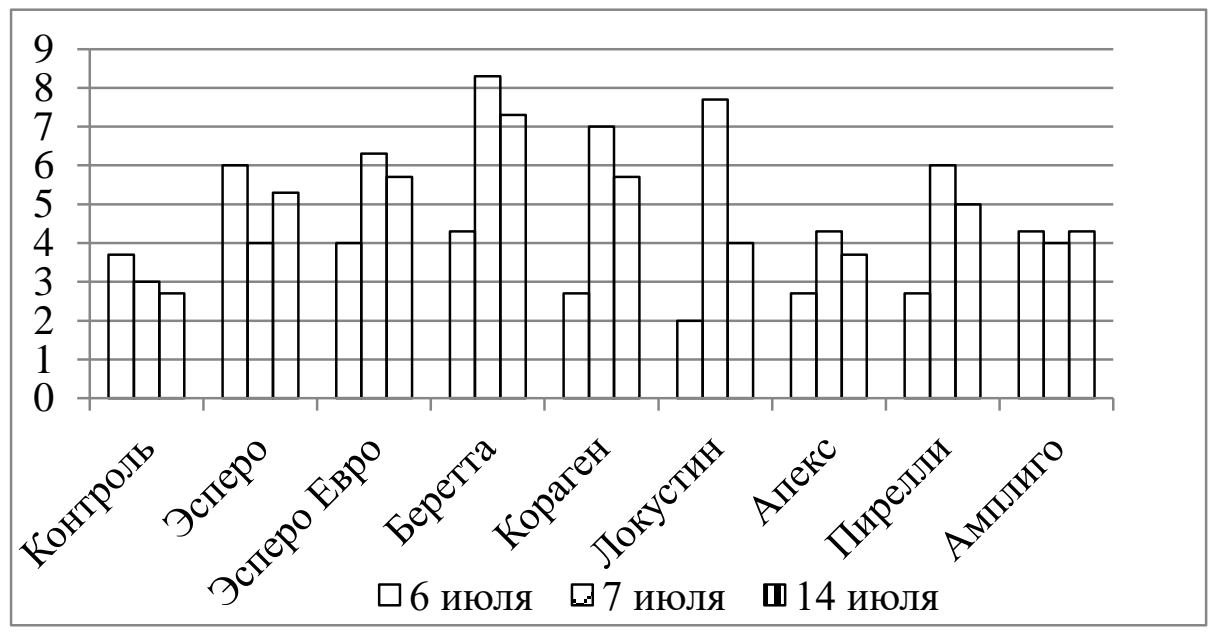

Рис.1 Влияние инсектицидов на численность опылителей в посевах ярового рапса, шт./делянку

Инсектицидные обработки в определенной степени улучшали некоторые структурные показатели урожайности рапса, такие как число стручков на главном побеге и массу семян в 10 стручках (табл. 2). 
Таблица 2 - Влияние инсектицидных обработок на некоторые структурные показатели урожайности рапса

\begin{tabular}{|l|l|l|l|}
\hline \multirow{2}{*}{ Вариант } & \multicolumn{3}{|l|}{ Структурные показатели } \\
\cline { 2 - 4 } & $\begin{array}{l}\text { Среднее число стручков на } \\
\text { главном побеге }\end{array}$ & $\begin{array}{l}\text { Масса семян в } 10 \\
\text { стручках }\end{array}$ \\
\hline 1. Контроль & 14,16 & 0,87 \\
\hline Эсперо, КС, 0,2 & 15,17 & 0,84 \\
\hline Эсперо Евро, МД, 0,4 & 15,58 & 0,95 \\
\hline Беретта, МД, 0,4 & 16,92 & 0,91 \\
\hline Кораген, КС, 0,2 & 12,07 & 0,93 \\
\hline Локустин, КС, 0,4 & 14,7 & 0,91 \\
\hline Апекс, МД, 0,5 & $17,46^{*}$ & 0,96 \\
\hline 10.Пирелли, КЭ, 1,0 & 15,92 & $1,03^{*}$ \\
\hline 11.Амплиго, МКС, 0,3 & $19,18^{*}$ & $1,02^{*}$ \\
\hline НСР $_{05}$ & 2,98 & 0,12 \\
\hline
\end{tabular}

*- разница превышает $\mathrm{HCP}_{05}$

\section{Выводы}

Подводя итоги, следует отметить, что в прессе в последние годы активно обсуждается проблема гибели пчел в агроценозах при химических обработках. Следует учесть, что инсектицидные обработки против рапсового цветоеда на рапсе должны проводиться в начале бутонизации, когда цветов еще нет, во-первых с целью наиболее эффективного подавления вредителя, а во- вторых, для минимизации отрицательного действия на опылителей. Наши исследования свидетельствуют об отсутствии отрицательного влияния инсектицидов на количество опылителей. Однако при этом не снимается вопрос токсикологического изучения меда и других пчелопродуктов.

\section{Библиография}

1. $\quad$ https://agrovesti.net/, https://ab-centre.ru дата обращения 12.09.2019

2. Власенко Н.Г., Парамонова Т.П., Штундюк Д.А. Защита рапса от вредителей всходов // Защита и карантин растений 1998. №8. С. 27.

3. Кулагин О.В. Испытание новых инсектицидов в борьбе с вредителями рапса // Межд. научн-практ. конф. «Развитие сельского хозяйства на основе современных научных достижений и интеллектуальных цифровых технологий «Сибирьагробиотехнологии» САБИТ-2019. Новосибирск, 2019. С.52-53. 